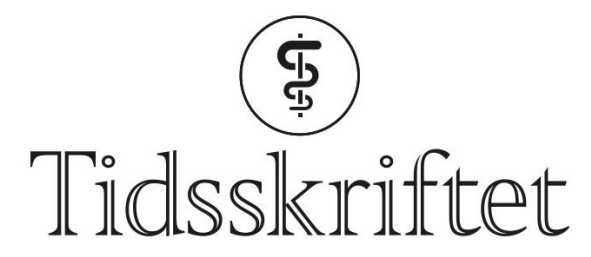

DEN NORSKE LEGEFORENING

\title{
- Veldig mange stempler tjukke mennesker som dumme
}

REPORTASJE

IRENE THORESEN RØNOLD

E-post: irene.thoresen.ronold@tidsskriftet.no Tidsskriftet

- I alle år har leger fortalt meg at jeg var for tjukk, forteller Laila Oliversen Brandsgård. Likevel måtte hun bli 42 år gammel før en lege spurte om hun ønsket behandling for overvekten.

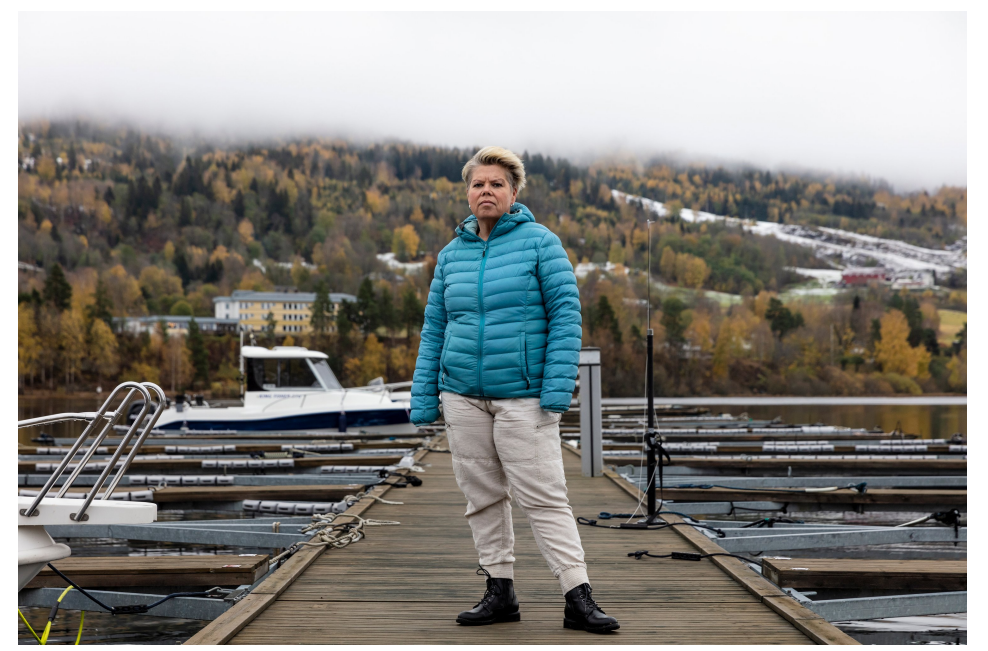

Laila Oliversen Brandsgård hadde sykelig overvekt i mange år, og hadde på det meste en BMI på 47 $\mathrm{kg} / \mathrm{m}^{2}$. Hun gir hjelp fra en fastlege mye av ceren for at hun har gått ned 6o kilo i forbindelse med en fedmeoperasjon. Foto: Christian Tunge

- Jeg har i alle år ønsket å gå ned i vekt og var hele tiden på leit etter hjelp til å klare det. Det lå i bakhodet hele tiden, forteller 53 år gamle Laila Oliversen Brandsgård.

I mange år hadde hun sykelig overvekt. På det meste hadde hun en BMI på 47. Hun startet sin reise med livsstilsendring i 2005. Siden har hun gått ned nesten 6o kilo, blant annet ved hjelp av en fedmeoperasjon.

- Leger jeg har møtt, har fortalt meg at jeg var for tjukk. «Du må ned i vekt. Du må bare skjerpe deg. Du må skjønne at du må spise mindre og trene mer». Og det var det. Ferdig, forteller hun.

- Hvordan var det for deg som pasient å få den beskjeden?

- Du knekker helt sammen. Du føler at det ikke nytter, at du ikke har god kommunikasjon 
med legen. Da blir det enda vanskeligere å ta opp at du har lyst til å gå ned i vekt. Du er redd for å bli møtt med en pekefinger.

\section{Den nye folkesykdommen}

Overvekt er i ferd med å bli den nye folkesykdommen. Tall fra Helseundersøkelsen i Trøndelag (HUNT) viser at 6o-70 \% av Norges befolkning er overvektige (1). Hvis du er en normalvektig voksen i 2020, tilhører du med andre ord mindretallet.

Likevel viser en rekke studier at personer med fedme er sårbare for diskriminering i en rekke sammenhenger (2). Ofte blir vekta forstått som noe som skyldes latskap og mangel på selvdisiplin, og helsevesenet er dessverre ikke noe unntak. I 2020 viste blant annet en norsk doktorgrad at intensivsykepleiere har fordommer mot pasienter med fedme (3). De ser på dem som late og tunge å håndtere.

Brandsgård har selv opplevd at overvekt og matvaner har fått skylden for det meste av helseproblemer hun har hatt. Da hun gikk første året på videregående skole, fikk hun intense magesmerter.

- Jeg tror jeg gikk med disse smertene i fem eller seks år. Jeg var inn og ut hos diverse fastleger, ettersom hvor jeg bodde. Alle leger jeg var i kontakt med, sa at smertene helt sikkert skyldtes at jeg spiste feil, sier hun.

Etter at hun hadde tatt utdannelse som hjelpepleier, begynte hun å jobbe på et sykehus. Der kom hun en dag over et tidsskrift hvor hun leste om helicobacter pylori-bakterien, som kan føre til magesår. Hun ba fastlegen om å få en gastroskopi. Den viste - ganske riktig - et helicobacter pylori-relatert sår på tolvfingertarmen, forteller hun.

- Behandlingen er to uker med antibiotika. Så er du kvitt det. På to uker ble jeg kvitt flere år med sterke smerter. Jeg kunne sikkert ha blitt blitt tatt på alvor før og blitt behandlet mye før.

- Tror du overvekt var årsaken til at det ikke ble oppdaget? Magesmerter kan jo henge sammen med kosthold?

- Absolutt. Men jeg følte at min beskrivelse av smerte ikke ble tatt på alvor. Jeg ble avfeid med at «ting løser seg hvis du spiser normalt». Og jeg synes ikke at jeg spiste unormalt.
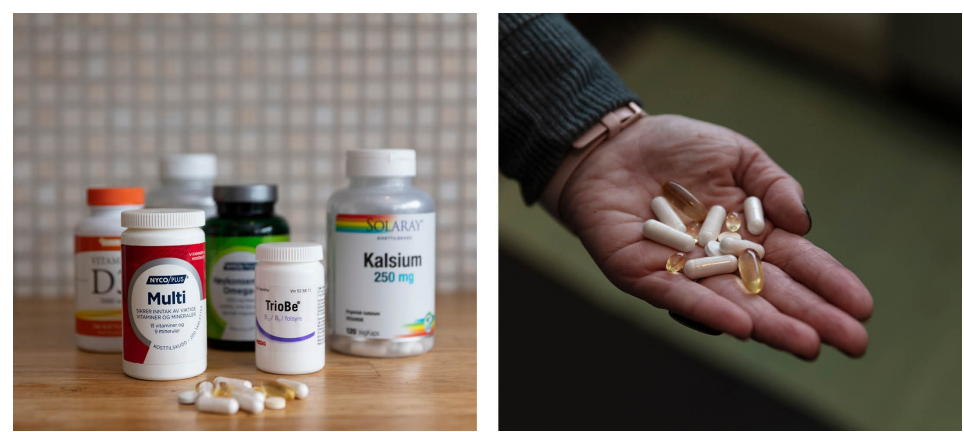

En håndfull med kosttilskudd hver dag må til for at Laila Oliversen Brandsgård skal få i seg alle nceringsstoffene hun trenger etter fedmeoperasjonen. Foto: Christian Tunge

\section{Ikke uvanlig med fordommer}

Mari-Mette Graff, leder for Landsforeningen for overvektige, har hørt flere liknende historier. En vanlig opplevelse er at overvekten får skylden for alt av helseproblemer - om det så er snakk om øreverk eller en forkjølelse. Andre historier handler om ydmykende situasjoner.

- Jeg hørte om en gravid kvinne som ble sendt til legen fordi hun opplevde blødninger i svangerskapet. Legen hentet lytteutstyr for å høre om det var liv, men klaget over at det var vanskelig å høre noe når det var så mange lag fett. En bedre måte å løse den situasjonen på ville vært å si «her må vi ha mer avansert utstyr for å hjelpe deg», sier hun. 
Brandsgård har selv opplevd at overvekt og matvaner har fått skylden for det meste av helseproblemer hun har hatt

Jøran Hjelmesæth er leder for Senter for sykelig overvekt i Helse Sør- $\emptyset$ st ved Sykehuset i Vestfold og professor ved Universitetet i Oslo. I sitt arbeid møter han pasienter med en BMI på $35 \mathrm{~kg} / \mathrm{m}^{2}$ eller mer - altså fedme grad 2 eller 3 . Han er heller ikke i tvil om at det er mange overvektige som blir møtt med fordommer hos helsepersonell.

- Leger har nok minst like mye fordommer mot pasienter med overvekt som folk der ute i samfunnet. Det er vanskelig å ta opp ting på en respektfull måte hvis du mener at pasienten foran deg er lat og mangler selvdisiplin. Hvis du mener det, er det fort gjort å signalisere det også, sier han.

- Hva gjør dette med pasienten?

- Når man har et fedmeproblem og blir møtt med arroganse og fordommer, kan det føre til en internalisering av de fordommene. Man skammer seg, blir deprimert og får redusert livskvalitet. Det forverrer situasjonen. Særlig fordi følelsesmessig spising ofte kan være en del av fedmeproblemet. Så det kan være veldig skadelig. Det er negativ behandling, slår Hjelmesæth fast.

\section{Arv og miljø}

Ifølge Hjelmesæth kan fedme forstås som en sykdom forårsaket av et fedmedisponerende samfunn.

- Vi kjenner til om lag hundre genvarianter som bidrar til fedme. Noen blir litt senere mette, er litt mer sultne og har litt tregere forbrenning. For å si det enkelt: Det finnes så mye billig, energitett mat der ute at de som er arvelig disponerte, har problemer med å stå imot, forteller han.

\section{Fedme}

Overvekt defineres som det å ha en kroppsmasseindeks (BMI) på 25-30 kg/m². BMI på $\geq 30$ er fedme. Det er først og fremst fedme som er forbundet med $ø$ kt helserisiko.

Om lag 1 av 4 menn og 1 av 5 kvinner i aldersgruppa 40-50 år har fedme. Andelen har $\emptyset \mathrm{kt}$ de siste 40-50 årene.

Resultater fra Tromsøundersøkelsen og Helseundersøkelsen i Trøndelag (HUNT) tyder på at flertallet av voksne i Norge enten har overvekt eller fedme.

Data fra HUNT-undersøkelsen tyder på at blant voksne med BMI > 35 har nesten halvparten sykelig fedme. Det vil si at de enten har følgesykdommer eller en BMI $\geq 40 \mathrm{~kg} / \mathrm{m}^{2}$.

Kilde: Folkehelseinstituttet (5)

Brandsgård tror årsakene til hennes overvekt ligger i en kombinasjon av arv og miljø. Flere i hennes familie - fra oldemoren og ned - er overvektige. I tillegg har hun slitt med hormonproblemer, noe som for mange gjør det lettere å legge på seg. I perioder hvor livet har vært vanskelig, har hun brukt mat og overspising som følelsesregulator.

- Når man har genetikken labil i kroppen, eskalerer det fort, sier hun.

\section{$\emptyset$ nsker at legen skal ta initiativ}

Til tross for at det finnes negative historier og opplevelser: Svært mange pasienter med overvekt $\emptyset$ nsker at legen skal ta det opp. 


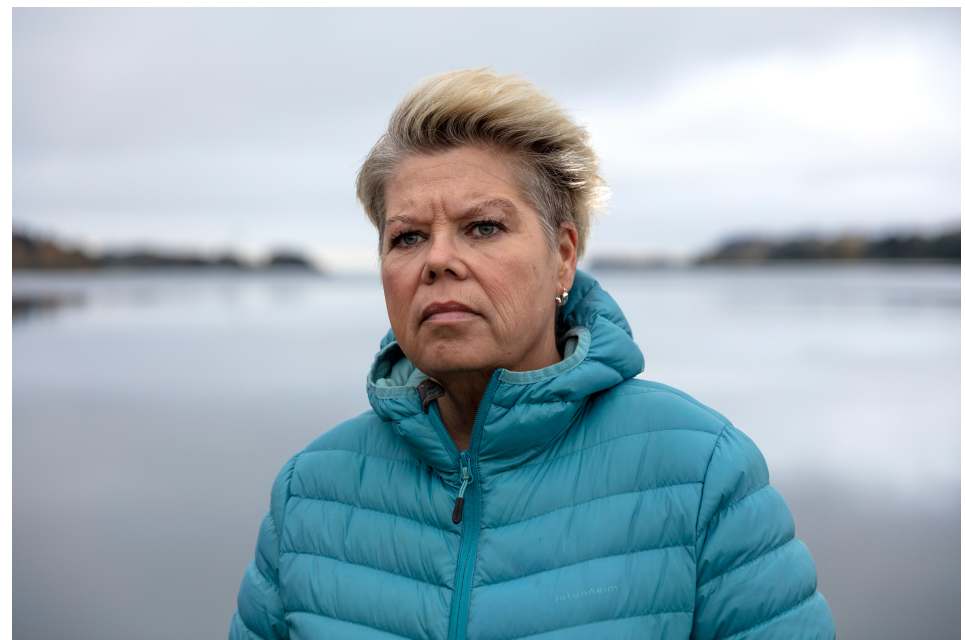

Laila Oliversen Brandsgård forteller at hun blir møtt på en helt annen måte $i$ dag enn for ti år siden.Veldig mange stempler tjukke folk som dumme. Nå ser folk på meg på en helt annen måte, forteller hun. Foto: Christian Tunge

I en internasjonal studie fra 2019 der pasienter og leger ble spurt om sine holdninger til overvekt, oppga syv av ti pasienter med overvekt at de gjerne ville at legen skulle ta initiativ til å snakke om fedmen og eventuell behandling (4). Likevel opplevde svært få at det skjedde. Mari-Mette Graff sier studien stemmer overens med hennes erfaringer.

- Veldig mange forteller at fordi de skammer seg sånn, skulle de ønske legen tok initiativ til å snakke om overvekten. De synes det er vanskelig å ta det opp selv og er redd for at legen ikke kommer til å forstå dem, sier hun.

Veldig mange forteller at fordi de skammer seg sånn, skulle de ønske legen tok initiativ til å snakke om overvekten

Hun mener at det ligger i legens mandat å snakke om overvekt med pasienten, og at det er både legitimt og ønskelig at det skjer. Men det må skje på en ordentlig måte.

Hun får støtte fra Jøran Hjelmesæth. Han tror mange pasienter med overvekt ser på vektproblemet som noe selvforskyldt som de ikke ønsker å plage legen med. Begge mener den beste måten å nærme seg temaet på, er å ta det opp på en respektfull måte, for eksempel ved å spørre om pasienten ønsker å snakke om sin vekt. Da får man mulighet til å vurdere om pasienten er klar for det eller ikke, sier Hjelmesæth.

- Det er ikke fordomsfullt å snakke om vekt. Det som er fordomsfullt, er å signalisere at vekten er uvesentlig eller selvforskyldt, sier han.

\section{En overveldende opplevelse}

Laila Oliversen Brandsgård var 42 år gammel og hadde levd med sykelig overvekt i mange år da det begynte å løsne. Under en konsultasjon spurte hennes nye fastlege om hun kunne tenke seg hjelp og behandling for overvekten.

- Tidligere har det ikke vært noen dialog. Men så møtte jeg en lege som hadde tid til meg og viste respekt for meg. Det var en overveldende opplevelse. Jeg gråt som en unge da jeg gikk ut derfra - fordi jeg for første gang følte at her er det noen som ser meg, som vil meg vel.

Etter den første konsultasjonen begynte Brandsgård å gå jevnlig til fastlegen. Sakte, men sikkert bygde det seg opp et tillitsforhold som gjorde at hun kunne åpne opp om ting hun hadde strevd med hele livet. Det ble etter hvert tydelig at hun var mottakelig for hjelp.

I første omgang var behandlingen fast trening med folkehelsekoordinator og et opphold på Tonsåsen rehabiliteringssenter, en tidligere behandlingsinstitusjon for sykelig overvekt. Hele veien fikk hun oppfølging fra fastlegen. Til sammen var hun på Tonsåsen tre ganger. Hun ble i bedre form, men overvekten slapp ikke taket.

Så møtte jeg en lege som hadde tid til meg og viste respekt for meg. Det var en overveldende 
opplevelse

- Jeg hadde prøvd lenge, i mange år. Jeg prøvde alle mulige slags kurer, jeg trente og hadde samtaler, men det var ikke nok. Når du har prøvd og prøvd og fortsatt har en sykelig overvekt som er farlig for helsa di, hva gjør du da?

Til slutt var det legen som under en av disse samtalene spurte om fedmeoperasjon kunne være noe for henne.

- Jeg var livredd. Du har hørt om operasjoner som går galt, og som enslig forsørger til et lite barn blir du jo redd for at noe skal skje med deg. Men jeg var enda reddere for at jeg skulle dø ung, sier hun, og fortsetter:

- Legen var veldig klar på det. Jeg hadde en sykdomshistorie som måtte tas på alvor. Mange i min familie har dødd av hjerteinfarkt i ung alder. Begge besteforeldrene mine døde i 6oårene. Pappa var 52. Mamma var 64. Jeg kom fram til at jeg var mer redd for å døav hjerteinfarkt enn å dø på operasjonsbordet. Derfor bestemte jeg meg for å ta en operasjon.

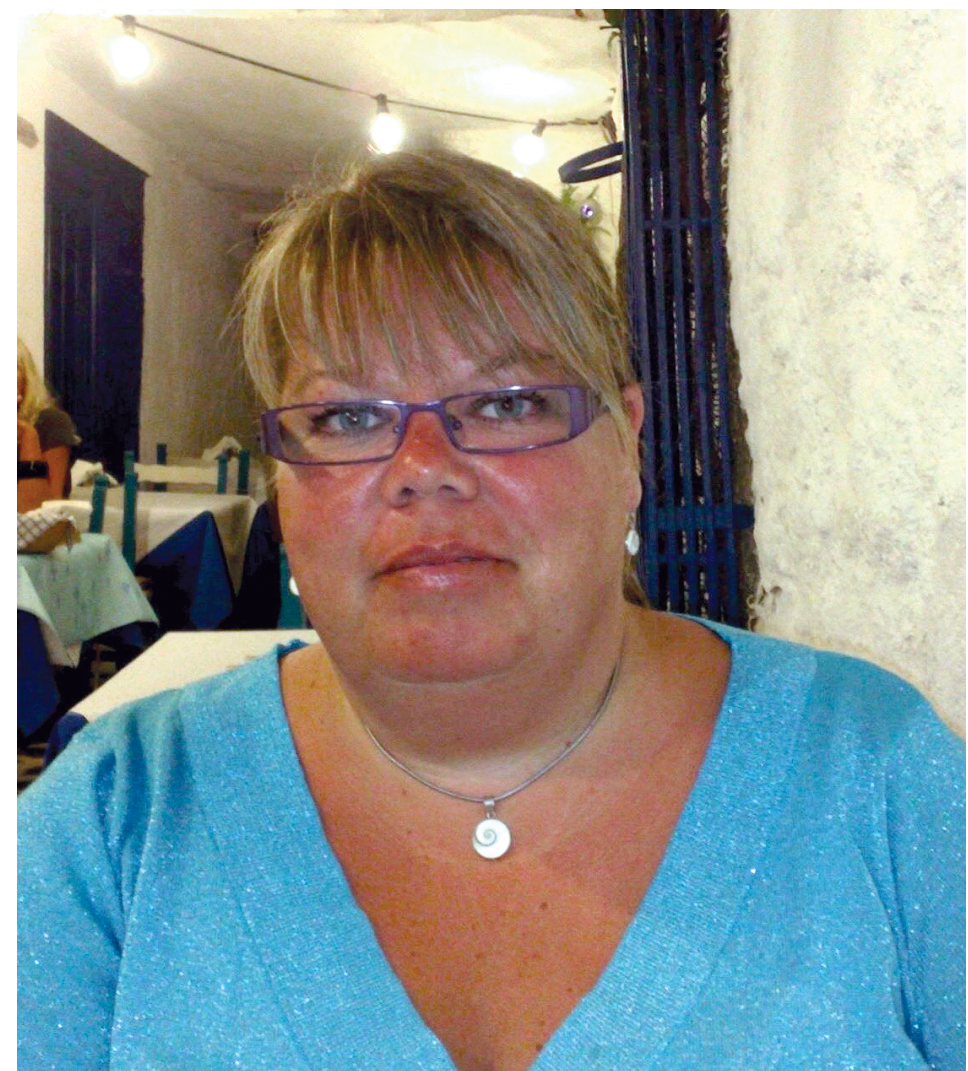

Da hun var på sitt tyngste, opplevde Brandsgård at overvekten fikk skylden for alle helseproblemer.Om jeg så hadde øreverk, omtrent, var det fordi jeg var for tjukk, forteller hun. Foto: Privat

\section{Et annet liv}

$\mathrm{Ni}$ år etter fedmeoperasjonen har Brandsgård gått ned hele 6o kilo. Mange av helseutfordringene hun hadde, som høyt blodtrykk, astma og migrene, har stabilisert seg. Livet er på mange måter enklere.

- Før var jeg ikke i stand til å gå mer enn en 15 minutters tur før jeg var helt utslitt. Nå er jeg veldig fysisk aktiv. Jeg trener fast med Frisklivssentralen to ganger i uka. I tillegg går jeg turer, sykler masse og er vanngyminstruktør på et treningssenter. Det er en helt ny verden, sier hun.

Det er ikke fordomsfullt å snakke om vekt. Det som er fordomsfullt, er å signalisere at vekten er uvesentlig eller selvforskyldt

Likevel er det mange forandringer som har vært vanskelige å forholde seg til. En av disse tingene er hvordan hun nå blir møtt som person. Hun har i mange år vært aktiv 
lokalpolitiker og opplevde at som overvektig kunne det være krevende å bli tatt på alvor.

- Veldig mange stempler tjukke mennesker som dumme. Nå ser folk på meg på en helt annen måte. Jeg føler at jeg blir tatt mer på alvor. Folk lytter til det jeg har å si.

- Hvordan oppleves det for deg?

- Det er sårt. Og jeg blir sinna, veldig sinna. Selv om jeg har forandret ytret mitt, er jeg den samme på innsiden.

\section{Hvordan snakke med pasienter om vekt?}

Er du usikker på hvordan du skal snakke med en pasient om overvekt? Jøran Hjelmesæth gir følgende råd:

- Ta opp vekten på en respektfull måte. Si for eksempel «Vil du at vi skal snakke om vekt?» Da får du mulighet til å forstå om pasienten er klar for å samtale om det eller ikke.

- Ved hjelp av teknikker som motiverende intervju kan du få pasienten selv til å foreslå endringer som vedkommende er motivert for. Spør gjerne: «Har du tenkt noe selv på hva du kunne gjort for å endre dette?». Hvis svaret er «trene mer og spise litt sunnere», må det konkretiseres. Hvilke konkrete tiltak passer for pasienten?

- Undersøk hvor det enkelt kan være noe å hente. For eksempel: juice er ikke direkte usunt, men det er kaloritett. Hvis pasienten drikker en liter juice om dagen, kan det være mye å hente på å bytte ut dette med et eple.

- Retningslinjene for behandling av fedme er at det krever tett oppfølging de første 3-6 månedene. Hvis man legger opp til en langsom vektreduksjon, er det best å få til en konsultasjon ukentlig i begynnelsen. Hvis det er vanskelig å få til i en travel praksis, kan videokonsultasjon være en god løsning. På lengre sikt kan man snakkes litt sjeldnere.

- Fortell pasienten at all vektreduksjon kan være bra for helsa. Selv 2-3\% vektreduksjon kan gi redusert risiko for en rekke følgesykdommer.

- Fedme oppfattes nå som en kronisk sykdom. Det betyr at det trengs livsvarig oppfølging. Husk at gammel vane er vond å vende. Det å endre spisemønster og levemåte er vanskelig. Da trenger man noen å snakke med underveis.

LITTERATUR:

1. Egge JH, Alisubh T, Aabakken E. Nå er 7 av 10 nordmenn overvektige. NRK 18.10.2018. https://www.nrk.no/trondelag/fedmeproblem-i-norge_-70-prosent-av-folket-er-overvektige-1.14244273 Lest 26.10.2020.

2. Rubino F, Puhl RM, Cummings DE et al. Joint international consensus statement for ending stigma of obesity. Nat Med 2020; 26: 485-97. [PubMed][CrossRef]

3. Robstad AN. Intensive care nurses' attitudes and behavioural intentions toward obese intensive care patients. Doktorgradsavhandling. Kristiansand: Universitetet i Agder, 2020. https://uia.brage.unit.no/uia-xmlui/handle/11250/2655168 Lest 26.10.2020.

4. Caterson ID, Alfadda AA, Auerbach P et al. Gaps to bridge: Misalignment between perception, reality and actions in obesity. Diabetes Obes Metab 2019; 21: 1914-24. [PubMed][CrossRef]

5. Folkehelseinstituttet. Overvekt og fedme i Noreg.

https://www.fhi.no/nettpub/hin/ikke-smittsomme/overvekt-og-fedme/ Lest 26.10.2020. 
Publisert: 9. november 2020. Tidsskr Nor Legeforen. DOI: 10.4045/tidsskr.20.0856

(C) Tidsskrift for Den norske legeforening 2020. Lastet ned fra tidsskriftet.no 